\title{
Podstawowe sprzeczności podporządkowanego kapitałowi szkolnictwa wyższego. W stronę systematyzacji
}

\begin{abstract}
STRESZCZENIE. W niniejszym artykule badamy szczegółowo cztery główne sprzeczności współczesnego szkolnictwa wyższego podporządkowanego kapitałowi. Dokonujemy tego zarówno na podstawie wcześniejszych wyników badań, jak i z wykorzystaniem marksistowskich i autonomistycznych ram teoretycznych, rozwiniętych przez takich autorów, jak Michael Hardt, Antonio Negri i Gigi Roggero, i stosowanych niedawno w krytycznych badaniach nad szkolnictwem wyższym. Sprzeczności zostały podzielone na dwie kategorie: sprzeczności pozorne (to, co publiczne i to, co prywatne; oligarchia akademicka i kapitał) oraz sprzeczności realne (poddana rozkładowi forma tego, co wspólne i dobro wspólne; dobro wspólne i kapitał). Zostały one omówione w odniesieniu do współczesnej rzeczywistości szkolnictwa wyższego. W ostatniej części artykułu prezentujemy zaś warunki wstępne ustanowienia postkapitalistycznego uniwersytetu regulowanego według logiki dobra wspólnego.
\end{abstract}

SŁOWA KLUCZOWE: dobro wspólne, szkolnictwo wyższe, uniwersytet, subsumcja, kapitał, publiczne, prywatne

\section{Wprowadzenie}

Od wielu lat autorzy i autorki ze wszystkich stron akademickiej sceny politycznej prześcigają się w rozwijaniu krytycznych narracji dotyczących głębokiego kryzysu instytucji współczesnego uniwersytetu. Większość z nich łączy to, że poruszają się w ramach konceptualnego horyzontu wyznaczonego przez liberalną filozofię i ekonomię polityczną. W związku z tym w narracjach tych korporatyzacja (Schrecker

${ }^{1}$ Tekst powstał w ramach mojej pracy w projekcie badawczym „Europejskie uniwersytety flagowe: w poszukiwaniu równowagi między doskonałością akademicką a zobowiązaniami wobec społeczeństwa i gospodarki (FLAGSHIP)" finansowanym ze środków Narodowego Centrum Nauki (UMO-2013/10/M/HS6/00561). 
2010), utowarowienie (Oliveira 2013), prywatyzacja (Ball i Youdell 2008), urynkowienie (Jongbloed 2003) oraz ekspansja kapitalizmu akademickiego w murach uniwersytetu (Leslie i Slaughter 1998) są zwykle przeciwstawiane umacnianiu publicznego charakteru tej instytucji (Barnett 2015) lub jej ponownemu upublicznieniu (Marginson 2006).

Przekonująca diagnoza tego problemu oraz jego możliwe rozwiązania, unikające wspomnianych ograniczeń, wyrosły ze stanowiska marksizmu postoperaistycznego, zwanego również marksizmem autonomistycznym (Hall 2015). Publikacje w rodzaju książek kolektywu Edu-factory (2009) czy Production of living knowledge włoskiego socjologa i aktywisty Gigiego Roggero (2011a) raz jeszcze rozbudziły wyobraźnię aktywistów na całym świecie (Haiven 2014), przyczyniając się do ponownego otwarcia dyskusji o kondycji uniwersytetu i możliwych drogach wyjścia z kryzysu. Wspomniany Roggero formułuje w tym kontekście tezę o podwójnym kryzysie przenikającym zarówno instytucje akademickie, jak i kapitalistyczną gospodarkę jako całość, w której centrum coraz częściej umieszczane są uniwersytety. Kryzys gospodarczy rozumiany jest tu jako kryzys kapitalizmu jako takiego, kondycja permanentna, na którą składają się przede wszystkim niezdolność do pomiaru efektywności i skutecznego koordynowania procesu produkcji biopolitycznej oraz nieumiejętność stosowania innej formy przechwytywania wytworzonego bogactwa niż operacje finansowe. Kryzys uniwersytetu widziany jest zaś w perspektywie trzech trendów, z których najistotniejszy jest koniec dialektyki między tym, co publiczne, a tym, co prywatne (Szadkowski 2015c). Jak twierdzi Roggero, leczenie bolączek utowarowiania wiedzy i edukacji oraz wprowadzanie logiki zysku w obręb murów uniwersyteckich nie jest już dłużej możliwe z racji ściślejszej państwowej kontroli nad sektorem. Publiczne uniwersytety, poddane reformom przygotowanym zgodnie z założeniami Nowego Zarządzania Publicznego, stają się hybrydami. Poprzez następujące po sobie fale reform na publicznych uniwersytetach zwiększa się poziom konkurencji między instytucjami, kadrą i studentami. Wprowadza się nowe instrumenty budżetowe oparte na wskaźnikach wydajności, kładzie się większy nacisk na wyniki oraz ich bezpośredni pomiar, a także koncentruje się finansowanie w najbardziej „efektywnych” jednostkach, różnicując tym samym wertykalnie instytucje w ramach danego narodowego systemu szkolnictwa wyższego. Ponadto

${ }^{2}$ W niniejszym tekście, definiując pojęcie pracy biopolitycznej, podążam za Michaelem Hardtem i Antoniem Negrim, którzy w Rzeczy-pospolitej (2012) piszą, że ,jest to praca, której wytworami są afekty, relacje społeczne, wiedza, obrazy, informacja, kody, formy życia i podmiotowości” (232, 383), która jest „w coraz większym stopniu autonomiczna wobec kapitalistycznej kontroli, odkąd jej schemat kooperacji nie jest dłużej zapewniany z zewnątrz przez kapitał" (382). Wartość wytwarzana przez pracę biopolityczną jest „niemierzalna lub raczej stale przekracza miary jakichkolwiek schematów pomiaru” (383). Jej „produktywność [...] wymaga autonomii” (404). Jest twórcza, a „twórczość ta jest wyrazem dobra wspólnego" (431). W coraz większym stopniu przybiera cechy działania bezpośrednio politycznego (473). 
nieustanne podkreślanie prywatnych korzyści z edukacji (np. premii płacowej) prowadzi do tego, że wykształcenie widziane jest coraz częściej jako dobro prywatne.

Skoro to, co publiczne nie stanowi już - według autonomistów - właściwej drogi wyjścia z obecnego kryzysu, to gdzie powinniśmy szukać sposobu jego zażegnania? W niniejszym tekście za reżim konstytutywny dla pola akademickiego jako takiego, stający się coraz bardziej fundamentalnym zarówno dla produkcji akademickiej, jak i kognitywnej gospodarki kapitalistycznej, uznawany jest reżim dobra wspólnego (Roggero 2011b). Zanim przejdziemy do argumentacji, zdefiniujemy pewne podstawowe pojęcia.

$\mathrm{W}$ wielu analizach dochodzi bowiem do pomieszania dwóch pojęć z dwóch odrębnych poziomów, mianowicie „dobro wspólne” (to, co wspólne) mylone jest z podobnym pojęciem występującym w liczbie mnogiej - „dobrami wspólnymi”. Między tymi pojęciami jest jednak istotna różnica. „Dobra wspólne” odnoszą się do najbardziej namacalnego elementu rzeczywistości. Należy przez nie rozumieć przede wszystkim określone zasoby, zarówno o „naturalnym” czy „materialnym”, jak i „społecznym” czy „niematerialnym” charakterze. Cechą, która je opisuje, jest nieoddzielność od danego podmiotu zbiorowego, grupy czy całej klasy. Zasoby, które określamy jako dobra wspólne, są kluczowe dla reprodukcji danej zbiorowości.

Z kolei „to, co wspólne” tworzy najbardziej ogólny, ontologiczny poziom, na którym uchwytna jest wspólnotowa specyfika rzeczywistości społeczno-polityczno-gospodarczej. „Dobro wspólne” ma charakter procesu zdolnego do przechodzenia w postać instytucji. Specyfika materialistycznej teorii dobra wspólnego sprowadza się do tego, że w odróżnieniu od licznych socjologicznych czy ekonomicznych teorii dóbr wspólnych (Ostrom 1990; Hess i Ostrom 2007; de Angelis 2007) łączy wszystkie trzy poziomy, zamiast skupiać się wyłącznie na kwestii wąsko rozumianych zasobów. Natomiast w odróżnieniu od politycznych, religijnych czy etycznych rozważań o dobru wspólnym (Śpiewak 1998), umieszczających je w jakimś transcendentnym względem pola społeczno-gospodarczego porządku (czy będzie to ideał regulacyjny, porządek boski, czy samoistna i autonomiczna sfera tego, co polityczne), czyni z niego zachodzący na poziomie immanencji proces samostanowiących o sobie i samoprzekształcających się podmiotowości. Materialistyczna teoria dobra wspólnego zakłada zatem opartą na tym, co wspólne, ontologię immanencji, przyjmując procesualne i dynamiczne ujęcie dobra wspólnego, które w ramach praktyki uwspólniania przekształca otaczający świat i samo siebie w nieoddzielne od tego procesu wspólne zasoby podległe demokratycznym decyzjom podejmowanym przez wytwórców.

\section{Przyjęte założenia}

W niniejszym tekście w sposób milczący przyjmujemy kilka założeń dotyczących współczesnych transformacji szkolnictwa wyższego (szerzej: Szadkowski 2015a). 
To one stanowią punkt wyjścia prezentowanych tu rozważań, jak również wskazują na ich znaczenie i aktualność. Nim przejdziemy do głównej części, warto je pokrótce zarysować.

Po pierwsze, podążając za teoretykami kapitalizmu kognitywnego (Moulier Boutang 2011; Ratajczak 2015), traktujemy wyłonienie się i okrzepnięcie „gospodarek opartych na wiedzy", w których rozwój uwikłany jest współczesny uniwersytet, jako kolejny etap rozwoju antagonistycznego stosunku między pracą a kapitałem, obejmującego obszary związane z produkcją wiedzy, afektów i stosunków społecznych, w których główną rolę odgrywa przechwytywanie nadwyżki wytworzonej przez autonomicznych wytwórców. Uznaję jednak, że te metody przechwytywania, w zależności od rodzaju aktywności i stopnia jej podporządkowania kapitałowi, nie muszą się dziś różnić od metod stosowanych wcześniej w przypadku wydobywania wartości dodatkowej z produkcji przemysłowej, szczególnie opartej na pracy fizycznej. Niemniej za postoperaistami uznajemy założenie o współcześnie rosnącym znaczeniu kapitalistycznej renty (Vercellone 2010), to znaczy formy wydobywania nadwyżki, którą kapitał posługuje się, znajdując się poza bezpośrednimi procesami produkcji.

Po drugie, przyjmujemy, że choć umasowienie edukacji wyższej i intensywny rozwój badań naukowych były kluczowe dla nastania kryzysu fordyzmu i przejścia do kapitalizmu kognitywnego, dziś obie te sfery pełnią dla kapitału funkcje bezpośrednio produkcyjne. W przypadku szkolnictwa wyższego i nauki istotny jest fakt, że kapitał coraz częściej, zgodnie z postoperaistycznymi diagnozami, ulokowany jest na zewnątrz procesów wytwórczych. W tym kontekście mówimy o „stowarzyszeniu kapitałów" (Hall 2014; Szadkowski 2015b) podporządkowującym sobie szkolnictwo wyższe i badania jako całościowy system funkcjonujący w skali globalnej, wyróżniając przy tym kapitał produkcyjny (prywatne uniwersytety nastawione na zysk czy działania ponadnarodowe nastawione na zysk uniwersytetów publicznych i prywatnych nienastawionych na zysk; Breneman 2006), kapitał pieniężny/ finansowy (banki udzielające komercyjnych kredytów studenckich, McGettigan 2013; czy fundusze zarządzające uniwersyteckimi endowments, Cantwell 2016) oraz kapitał handlowy (duże międzynarodowe korporacje wydawców akademickich; Peekhaus 2012).

Po trzecie, wychodzimy z założenia, że w krajobrazie globalnego szkolnictwa wyższego możemy dostrzec różne formy hegemonicznych norm, wartości, języka, jak również form instytucjonalnych, w których owe normy są realizowane (Marginson i Ordorika 2011). Hegemonia w sektorze sprawowana jest przede wszystkim przez duże uniwersyteckie instytucje amerykańskie, zaś w mniejszym stopniu przez brytyjskie. Hegemonia w sferze szkolnictwa wyższego i nauki z jednej strony wzmacniana jest przez silną pozycję kapitalistycznych gospodarek krajów anglosaskich, z drugiej zaś - jest jedną z istotnych przyczyn powodzenia anglosaskich projektów ekonomicznych. Formami instytucjonalnymi, w których hegemonia ta jest 
realizowana, są, po pierwsze, procesy powstawania państwa ewaluacyjnego (Neave 2012) i wdrażania powiązanych z nim reform systemów szkolnictwa wyższego w paradygmacie Nowego Zarządzania Publicznego (Ferlie, Musselin i Andresani 2008), po drugie, wzorcowa forma współczesnego uniwersytetu badawczego, to znaczy publiczny uniwersytet przedsiębiorczy (Clark 1998), upowszechniany poprzez globalne rankingi uniwersytetów wzmacniające procesy instytucjonalnego izomorfizmu w globalnym sektorze szkolnictwa wyższego (Hazelkorn 2011; 2013; Szadkowski 2015b). To między innymi te dwie zinstytucjonalizowane formy hegemonii, jak zakładamy, odpowiedzialne są za proces zacierania granic (hybrydyzacji) między tym, co prywatne a tym, co publiczne w kontekście uniwersytetów publicznych (Roggero 2011).

Po czwarte, uważamy, że kres dialektyki między tym, co prywatne a tym, co publiczne czy między państwem a rynkiem jako mechanizmami koordynacji w szkolnictwie wyższym, który wyznaczają wzmiankowane wyżej procesy, jest również kresem produktywnej funkcji sposobów wyjaśniania opartych na koncepcjach urynkowienia, utowarowienia czy korporatyzacji, stosowanych zarówno w badaniach głównego nurtu nad szkolnictwem wyższym, jak i niektórych ich krytycznych odłamach (Szadkowski 2015a).

\section{Sprzeczności i napięcia w obrębie współczesnych systemów szkolnictwa wyższego}

Współczesne systemy szkolnictwa wyższego trapione są przez wiele napięć i wewnętrznych sprzeczności. Przede wszystkim obszary tego, co prywatne i tego, co publiczne, jak zauważają badacze głównego nurtu, ulegają coraz dalej idącej hybrydyzacji pod wpływem transformacji dokonujących się na globalnym, krajowym i lokalnym szczeblu. Przez hybrydyzację rozumiemy proces, w ramach którego formalnie publiczne instytucje zyskują coraz większą autonomię (finansową, organizacyjną, zatrudnieniową). Jednocześnie ze sfery polityki publicznej nieustanne płyną zachęty do zachowań przedsiębiorczych, ukierunkowanych na współpracę ze sferą gospodarczą. Instytucje stanowiące publiczną część sektora szkolnictwa wyższego uczestniczą więc jako aktywne podmioty w różnego rodzaju rynkach tworzonych i powstających samorzutnie w ramach sektora oraz działają na podstawie zasady „wewnętrznej skuteczności” nakazującej nieustannie redukować koszty własnej działalności i rozszerzać zakres dostępnych źródeł przychodów.

Tak rozumiana hybrydyzacja, nieodcinająca ostatecznie publicznego sektora szkolnictwa wyższego ani od ścisłej kontroli państwowej, wyznaczającej mu stale priorytety korzystne dla rozwoju kapitalistycznej gospodarki, ani od publicznego finansowania, umożliwiającego amortyzację ryzyka właściwego inwestycjom w sferze innowacji i rozwoju, jest zjawiskiem funkcjonalnym wobec procesów pomna- 
żania kapitału w sferze produkcji wiedzy. Co więcej, jest to zjawisko przez kapitał jak najbardziej pożądane. Zatem hybrydyzacja porząadków tego, co publiczne i tego, co prywatne to nie tyle stan przejściowy między ścisłą publiczną kontrolą sektora a jego kompletną prywatyzacją i podporządkowaniem rynkowi, ale właściwy, zapośredniczony w instytucji neoliberalnego państwa stan organizacji stosunków między szkolnictwem wyższym a kapitałem, odpowiadający potrzebom jego pomnażania i akumulacji.

Gdy przyjrzymy się jednak bliżej temu problemowi, okaże się, że przedstawione zjawiska znacznie wykraczają poza możliwości wyjaśniania oferowane w ramach interpretacji opartych na binarnej opozycji prywatne - publiczne. Co więcej, okaże się, że samo rozróżnienie na to, co publiczne i to, co prywatne jest funkcjonalne dla kapitału i rozgrywane zawsze zgodnie z jego interesem tam, gdzie akurat lokuje swoje zainteresowanie. Obserwowane przez wielu badaczy (Marginson 2007: 187; Kwiek 2010: 247) zjawisko zmieszania tych porząaków okazuje się więc jedynie epifenomenem szerszego procesu przygotowywania (na szczeblach globalnym, krajowym i lokalnym) sektora do warunków aktywności kapitału skupionego w tym, co można nazwać „transnarodowym stowarzyszeniem kapitałów” (Szadkowski 2015b; Hall 2014), rozwijającego się obecnie, zgodnie z wskazaniami wielu teoretyków i życzeniami równie wielu ustawodawców, przede wszystkim w oparciu o wiedzę.

Oprócz różnych form bezpośredniego podporządkowania pracy kapitałowi, towarzyszy temu proces idealnej subsumcji pracy kapitałowi w publicznym sektorze szkolnictwa wyższego. Idealna subsumcja jest czysto ideologiczną formą podporządkowania, której podstawowym polem odniesienia są sfery dyskursu i społecznych wyobrażeń. Sektory, w których podporządkowanie pracy kapitałowi zostało idealnie odwzorowane, kierują się inną logiką. Nie wyklucza to oczywiście tego, że idealna subsumcja pracy w danym sektorze może stanowić np. etap jego przygotowań do podporządkowania zachodzących w nim procesów kapitałowi funkcjonującemu na innym poziomie. Często jednak myli się ją z bezpośrednim formalnym bądź realnym podporządkowaniem pracy na uczelniach publicznych kapitałowi.

Niewystarczająco pogłębiona analiza zjawiska subsumcji (i różnych jego form) w obrębie sektora jest jedną z najważniejszych przyczyn ograniczeń, którymi obciążone są perspektywy mówiące o prywatyzacji, urynkowieniu czy korporatyzacji sektora, jak również ujęcia, które widzą we współczesnym uniwersytecie publicznym nową postać fabryki. Chcąc przekroczyć te analityczne ograniczenia, należy udzielić odpowiedzi na przynajmniej dwa pytania. Gdzie w szkolnictwie wyższym znajduje się kapitał? Jakie mechanizmy wykorzystuje w celu podporządkowania sobie pracy akademickiej, niezależnie od sektora (prywatnego lub publicznego), w którym jest ona wykonywana? Wobec tego należałoby zaproponować takie podejście analityczne, które w opozycji między kapitałem a dobrem wspólnym widziałoby zjawisko najważniejsze dla współczesnych przekształceń uniwersytetu, pozwalające zarówno wyjaśnić, opisane wyczerpująco w badaniach głównego nurtu, zjawisko hybry- 
dyzacji tego, co prywatne i tego, co publiczne, jak i dostarczyć precyzyjnego obrazu uniwersytetu w kryzysie. Widziany w ten sposób sektor szkolnictwa wyższego jawi się bowiem jako jeden z wielu sektorów kapitalistycznie zorganizowanej gospodarki i społeczeństwa.

Gdy odsłania się zarówno wszechogarniająca i prąca do zafałszowania stosunków społecznych figura kapitału, a także gdy na scenę wkracza dobro wspólne, prosta, zorganizowana w odniesieniu do dualnej opozycji prywatne - publiczne mapa sektora szkolnictwa wyższego zaczyna się wyraźnie komplikować. Kreślenie jej współrzędnych, uwzględniające dwa bieguny: kapitał i dobro wspólne, nie ma jednak na celu zastąpienia jednej dualnej opozycji drugą. Choć opozycja między kapitałem a tym, co wspólne ma znacznie większą niż inne pary ontologiczną gęstość i przecina rzeczywistość sektora szkolnictwa wyższego, z mniejszym lub większym natężeniem, we wszystkich jego aspektach, to nie jest jedynym obszarem w odniesieniu do którego można wyjaśniać konflikty w interesującym nas podsystemie społeczno-gospodarczym.

W tekście tym przedstawimy cztery najogólniejsze, opisane w abstrakcyjnych kategoriach, sprzeczności, które dotykają współczesny, podporządkowany kapitałowi, sektor szkolnictwa wyższego. Każda z opisanych sprzeczności tworzy wielorakie pola napięć i konfliktów, które konkretyzują się w różnych formach, niemożliwych tu do szczegółowego omówienia. Mimo przyjęcia z góry takiego ograniczenia wydaje się, że podjęta tu próba ma wcale niemałą wartość. Sama metoda ukazywania sprzeczności w obrębie podsystemów społeczno-gospodarczych podporządkowanych kapitałowi jest najbardziej podstawowym sposobem uprawiania krytyki w sensie marksistowskim. Celem takiej krytyki winno być otwarte, klarowne i odpowiednio uargumentowane odsłonięcie punktów zapalnych współczesnego kapitalistycznego ustrukturyzowania danego systemu, sektora czy pola. Jak pisał niegdyś Max Horkheimer, „bezpośrednim skutkiem teorii prącej do przekształcenia całego społeczeństwa”, a za taką uznajemy wszelką teorię krytyczną, a szczególnie prezentowane tu rozważania, ,jest zaostrzenie się walki, do której się ona włącza” (1987: 158). Ten rezultat można osiągnąć jedynie, porzucając próby godzenia biegunów, wydobywając na światło dzienne sprzeczności, a zarazem wskazując na możliwość ujścia ze szkodliwych relacji, które podważają zdolności do demokratycznego samostanowienia wytwórców w szkolnictwie wyższym.

Sprzeczności, na które chcielibyśmy wskazać w dalszej części, mają charakter podstawowy. Nie są one właściwe samemu sposobowi produkcji opartemu na kapitale, choć całą listę takich sprzeczności można byłoby tu sporządzić i dostosować do warunków panujących w sektorze szkolnictwa wyższego (Harvey 2014). Dotyczą one głównie zjawisk i problemów, które można przepisać na najogólniejsze kategorie tego, co prywatne, tego, co publiczne oraz tego, co wspólne (również w swojej poddanej rozkładowi, hierarchicznej postaci) i kapitału. Jeśli przyjmiemy za Simonem Marginsonem (2004) i Fernandem Braudelem (1998), że rynki i kapitalizm, 
stosunki wymiany i stosunki podporządkowania pracy kapitałowi w produkcji są czymś odrębnym (traktując zarówno rynek, jak i wymianę jako znacznie starsze od kapitalizmu zjawiska ekonomiczno-kulturowe), to kapitał uzyska oddzielny ontologiczny status. Tym samym kapitał należy uznać za odrębny od rynku mechanizm koordynacji sektora szkolnictwa wyższego (Clark 1983).

\section{Specyfika sprzeczności w szkolnictwie wyższym. Próba klasyfikacji}

W wielu opracowaniach i wypowiedziach publicystycznych wskazuje się na takie lub inne przejawy hybrydyzacji porządków tego, co publiczne i tego, co prywatne jako źródło kryzysu trapiącego współczesne szkolnictwo wyższe. Poczucie kryzysu uniwersytetu, które towarzyszy wielu badaczom szkolnictwa wyższego, jak i wielu uczestnikom tego pola, nie jest jednak czymś wyjątkowym. Kryzys jest nieodłącznie związany z funkcjonowaniem kapitału, a współczesny uniwersytet znajduje się obecnie pod jego wpływem. Kryzys otwiera przed kapitalistycznie ustrukturyzowanym uniwersytetem możliwości dalszych przekształceń, będących odpowiedzią - zgodnie z logiką opisaną przez Marksa - na napotykane kolejno ograniczenia. Jak pisze David Harvey „kryzysy są momentami transformacji, w ramach których kapitał najczęściej wymyśla siebie na nowo, przepoczwarzając się w coś innego" (2014: 4). W trakcie kryzysów ujawniają się jednak najbardziej istotne sprzeczności systemu, wystawiając go na szczególny rodzaj niestabilności, która może stanowić szansę zarówno dla podmiotów wytwórczych, jak również dla zaangażowanego w polu kapitału, który poprzez kryzys może się odnowić, by działać następnie ze zwielokrotnioną siłą.

Najczęściej powtarzaną dziś przez badaczy szkolnictwa wyższego receptą na kryzys uniwersytetu jest powrót do stanu sprzed tego rozedrgania, tak jakby można było w prosty sposób odwrócić zmiany, jakie dokonały się w ostatnich dekadach. Pamiętajmy jednak, że kryzys jest zawsze momentem decyzji. Krytyka ukazująca sprzeczności w ich możliwie najwyraźniejszej postaci może ułatwić jej podjęcie. Jednak podstawową funkcją analiz odsłaniających sprzeczności winno być napełnianie nadzieją, budzenie woli działania i wskazywanie prowadzącej naprzód drogi, nie zaś wzmacnianie bezradności tych, którzy w trakcie kryzysu znaleźli się w zasięgu negatywnego oddziaływania systemowych sprzeczności. Funkcjonalność kryzysów dla reprodukcji kapitalistycznego systemu produkcji w danym sektorze polega na tym, że pozwala kapitałowi na ucieczkę do przodu. Kiedy my wciąż żyjemy nostalgią za sposobem organizacji, który już dawno przeminąl, kapitał patrzy w przyszłość. Otwarcie się na odsłaniane w ramach kryzysu sprzeczności ma umożliwić nam zrobienie kroku naprzód, a więc również skuteczniejszą walkę. A być może nawet ucieczkę od kapitału. 
Pisząc o sprzecznościach, nie mamy na myśli sprzeczności w rozumieniu arystotelesowskim, w rodzaju słynnego stwierdzenia Stagiryty „niepodobna, ażeby coś zarazem było i nie było", w jej trzech, wyróżnionych przez Jana Łukasiewicza (1987), znaczeniach: ontologicznym, logicznym i psychologicznym. Bliżej nam z pewnością do rozpowszechnionego w ramach marksizmu, posiadającego heglowską proweniencję, dialektycznego pojmowania sprzeczności, które znacznie lepiej nadaje się do rozpoznawania istoty zjawisk społecznych. Każdy system, w którym mamy do czynienia z realnym rozwojem, zawiera w sobie sprzeczność. Sprzeczność bowiem jest główną właściwością rozwoju i jego podstawową zasadą. Dialektyczny sposób rozumienia sprzeczności dobrze uchwycił radziecki, lecz pozostający w opozycji do oficjalnej ortodoksji, marksista Ewald Iljenkow, pisząc:

[...] rzeczywistość zawsze rozwija się przez pojawienie się w niej konkretnej sprzeczności, która z kolei znajduje rozstrzygnięcie dzięki stworzeniu nowej, wyższej i bardziej skomplikowanej formy rozwoju. W pierwotnej postaci sprzeczność jest nieprzezwyciężalna. Wyrażona w myśleniu, istotnie jawi się jako sprzeczność w określeniach pojęcia odbijającego wyjściowe stadium rozwoju. Jest to nie tylko poprawna - jest to jedyna prawidłowa forma postępu myśli badawczej, choć w niej również zawarta jest sprzeczność. Tego rodzaju sprzeczność w określeniach przezwycięża się nie przez uściślanie pojęcia odbijającego daną formę rozwoju, lecz na drodze dalszego badania rzeczywistości, przez odnalezienie tak innej, nowej, wyższej formy rozwoju, w której wyjściowa sprzeczność znajduje rzeczywiste, faktyczne, empirycznie stwierdzalne rozwiązanie (Iljenkow 1978: 284).

Dialektyczny ruch sprzeczności miałby w tej perspektywie napędzać pochód dziejów, następstwo formacji społecznych i gospodarczych. Wydaje się jednak, jak wskazuje Antonio Negri (2003), że dziś ten ruch dobiegł końca lub utracił swą moc. Nie oznacza to jednak zgody na liberalne „teorie” głoszące wypełnienie się dialektyki dziejów w ostatecznym zwycięstwie kapitału czy jakiejś formie „końca historii”. Znacznie bliższa jest nam raczej wizja Negriego, który dowodzi, że na obecnym etapie rozwoju stosunków społecznych ruch dialektyczny dobiega kresu, a napięcie, jakie łączy kapitał z wyzyskiwanym dobrem wspólnym, może zostać rozładowane jedynie przez rozszczepienie tej relacji, ujście ze stosunków wyzysku czy ich ostateczne zerwanie. Moim zdaniem obecna sytuacja w szkolnictwie wyższym z całą mocą świadczy na rzecz tej diagnozy.

$\mathrm{Z}$ tego powodu ogólne sprzeczności występujące w sektorze szkolnictwa wyższego można podzielić na dwie grupy. Pierwszą z nich stanowią „sprzeczności pozorne", a więc takie, które zachodzą na powierzchni zjawisk i podlegają zarówno zafałszowaniu przez kapitał, jak i funkcjonalizacji względem niego. Bieguny takich sprzeczności pozostają ze sobą w antynomicznym napięciu, jednak granice między nimi są właściwie przepuszczalne, zatarte lub podlegają daleko idącej hybrydyzacji. Opowiedzenie się za którymkolwiek z członów tej pozornej opozycji nie pociąga 
za sobą również jej rozwiązania. Drugim rodzajem sprzeczności są „,sprzeczności realne", które mają charakter niedialektyczny. Oznacza to, że rozwiązanie danej sprzeczności nie prowadzi do zniesienia i w ten sposób zachowania w przekształconej postaci wchodzących ze sobą w tę relację elementów, lecz do zerwania stosunku i ostatecznego zaniku jednego z członów opozycji. Choć jeden z jej członów wchodzi w relację dialektyczną z drugim, funkcjonowanie drugiego członu ma potencjalnie charakter autonomiczny. Dla obu kategorii przedstawione zostaną po dwie sprzeczności o charakterze fundamentalnym, z których można wyprowadzić szereg innych sprzeczności. Według Davida Harveya (2014) mają one charakter ruchomy, to znaczy podlegają nieustannym historycznym i geograficznym przemianom, nabierają zupełnie nowego znaczenia, które należy zgłębiać wraz z kolejnymi transformacjami, które przechodzi dany sektor, gospodarka czy region.

\subsection{Sprzeczność pozorna (I): to, co prywatne i to, co publiczne}

Hybrydyzacja tego, co publiczne i tego, co prywatne, według krytycznych badaczy szkolnictwa wyższego, dowodzić ma, że nastał kres produktywnej dialektyki między tymi porządkami (Roggero 2011). Stopień ich zmieszania (pomijając samą problematyczność stwierdzenia o ich występowaniu kiedykolwiek wcześniej w jasno określonej, rozłącznej postaci; Latour 2011) jest na tyle wysoki, że trudno mówić o możliwość przywrócenia rzeczom ich „właściwego miejsca”. Zatem nie tylko trudno sobie wyobrazić, aby lekarstwem na niedomagania publicznego sektora mogło stać się jego większe urynkowienie (wewnętrzne i zewnętrzne), ale również interwencja skrajnie neoliberalnego państwa, tym bardziej że funkcjonuje ono w otoczeniu zdominowanym przez sprzyjające projektowi neoliberalnemu instytucje transnarodowe. Innymi słowy, współczesne państwo w coraz mniejszym stopniu może funkcjonować jako rozwiązanie problemów wynikłych z niedomagań rynku. Słabość tę szczególnie dobrze widać na poziomie globalnym, gdzie, zdaniem wielu teoretyków, rysuje się groźba utowarowienia globalnych dóbr publicznych wiedzy. Wszyscy zwolennicy aktywniejszej polityki państwa powinni również pamiętać, że państwo kapitalistyczne jest nie tylko gwarantem własności prywatnej, ale i głównym aktorem w ustanawianiu i podtrzymywaniu rynków.

W przypadku szkolnictwa wyższego trudno wskazać obszar, w którym dominowałyby dziś czyste formy państwowej i publicznej kontroli. Trudno też sobie wyobrazić powrót do dawnej biurokratyczno-państwowej postaci koordynacji sektora. W istocie to państwo jest dziś odpowiedzialne za wprowadzanie mechanizmów rynkowych do sektora, to również państwowe agencje stanowią główne źródła popytu na badania oferowane w ramach konkurencyjnych quasi-rynków dystrybucji środków. Sektor publiczny odpowiedzialny jest także za finansowanie z podatków lwiej 
części badań podstawowych, które następnie pozwala się prywatyzować uczelniom bądź indywidualnym naukowcom. Nieustannie formułowane są instytucjonalne zachęty do tworzenia takiej wiedzy, która daje się utowarowić bądź sprywatyzować.

Nie tylko jednak „transnarodowe stowarzyszenie kapitałów” jest w stanie realnie podporządkować sobie pracę akademicką w sektorze publicznym, ale również dominacja kapitału decyduje o urządzeniu sektora szkolnictwa wyższego w sposób właściwy podporządkowaniu pracy kapitałowi. Posiłkując się ustaleniami Marksa, moglibyśmy określić ten proces jako idealną postać subsumcji pracy kapitałowi w sektorze publicznym. Trudno sobie dziś wyobrazić podmiot, który w imię przywrócenia ładu w porządku publicznym przeprowadzilby gruntowną rewolucję, raz na zawsze odcinając ten sektor od wpływów rynków czy kapitału. Również badacze szkolnictwa wyższego czy, mówiąc ogólniej, teoretycy, socjologowie i ekonomiści głównego nurtu nie dają nam w tej kwestii większych nadziei. Świetnym przykładem jest noblista Joseph Stiglitz (1999), który pisząc o potrzebie tworzenia i podtrzymywania globalnych dóbr publicznych, ma na uwadze jedynie zdrowe i zrównoważone funkcjonowanie sektora prywatnych przedsiębiorstw, które w ten sposób można byłoby uratować przed „zawodnością rynku”.

Z tych i wielu innych powodów określamy napięcie, jakie przenika relację między tym, co prywatne a tym, co publiczne w szkolnictwie wyższym mianem „sprzeczności pozornej”, to znaczy takiej, która ujawnia się wyłącznie na powierzchni zjawisk, mając swe właściwe źródło w dynamice sił, zewnętrznej względem samej siebie, będąc w zasadzie zaledwie epifenomenem głębszego procesu.

\subsection{Sprzeczność pozorna (II): oligarchia akademicka i kapitał}

Rzeczywistość szkolnictwa wyższego nie daje się sprowadzić wyłącznie do opozycji między rynkiem a państwem. Ważnym jej elementem jest również względnie autonomiczna wspólnota akademicka, a więc podmiot, który przez wieki, z większym lub mniejszym powodzeniem, koordynował, przekształcał i rozwijał instytucję uniwersytetu. Czy jednak wspólnota akademicka w swojej zhierarchizowanej postaci jest czymś przeciwstawnym kapitałowi?

Dwa przykłady hybrydyzacji tego, co prywatne i tego, co publiczne w szkolnictwie wyższym, a więc przedsiębiorczość akademicka (Clark 1998), jako sposób na utrzymanie autonomii wspólnoty akademickiej, jak również powstanie kapitalizmu akademickiego (Slaughter i Rhoades 2004; Cantwell i Kaupinnen 2014), w którego rozwój aktywnie włączyli się przedstawiciele tejże wspólnoty, dowodzą niezbicie, że hierarchiczne zgromadzenie uczonych w swych relacjach z kapitałem jest raczej siłą nieantagonistyczną. Szczególnie w systemach czy instytucjach zajmujących pozycje centralne w ramach globalnego podziału pracy akademicy włączyli się w długotrwa- 
ły proces przeobrażania własnych instytucji w napędy gospodarki opartej na wiedzy (Berman 2012). Sprawowane przez nich rządy w instytucjach podlegających ich władzy bazują na oddzieleniu, podkopywaniu demokracji w miejscu pracy i często wzmacnianie są przez skłonności do menedżerskiego zarządzania. Funkcjonująca w danym krajowym sektorze szkolnictwa wyższego elita akademicka ${ }^{3}$ wychodziła najczęściej zwycięsko z transformacji, jaką na skutek spotkania z kapitałem w różnych postaciach przeszedł sam sektor. Wobec tego należałoby zapytać, czy kondycja idealnej, a niekiedy realnej subsumcji pracy kapitałowi w instytucjach szkolnictwa wyższego sprawia, że nie możemy już mówić o czymś takim, jak jednolita wspólnota akademicka? Hierarchiczne podziały, choćby w ramach formy stosunku pracy (upowszechnienie niestabilnych form zatrudniania akademików), dokonywane przez akademickich kolegialnych zarządców, podają istnienie takiej jednolitej wspólnoty w wątpliwość. Czołowi przedstawiciele świata nauki skwapliwie korzystają ze swego umocowania na szczycie hierarchii, by jeszcze bardziej wzmocnić własną pozycję w korzystnej relacji z kapitałem.

Jednak problemem nie jest tylko kwestia mniej lub bardziej demokratycznego regulowania stosunków w akademickim miejscu pracy. Większe znaczenie ma to, że kapitał wprzęga, instrumentalizuje i przekształca mechanizmy służące od wieków do regulowania hierarchii wewnątrz wspólnoty akademickiej w swoje procesy pomnażania wartości. Jak pisał Marks w trzeciej księdze Kapitatu, kapitał handlowy, który stanowi istotną frakcję transnarodowego stowarzyszenia, podporządkowującą pracę akademicką na całym świecie, ,jest z początku jedynie ruchem pośredniczącym między krańcami, nad którymi nie panuje, oraz między przesłankami, których nie stwarza" (Marks 1984: 504). Ta sytuacja jest jednak krótkotrwała, ponieważ - jak pisał dalej Marks - „handel wywiera wszędzie w większym lub mniejszym stopniu rozkładowy wpływ na organizacje produkcji, które zastaje, a które we wszystkich swych formach mają głównie wartość użytkową na względzie. Ale jak daleko sięga ów rozkładowy wpływ na dawny sposób produkcji, zależy przede wszystkim od trwałości tego sposobu i właściwej mu organizacji wewnętrznej" (Marks 1984: 507). Uniwersytet i szerzej: wspólnota naukowa są jednymi z najstarszych instytucji w świecie zachodnim, posiadają silną organizację wewnętrzną i są względnie odporne na zmiany. W związku z tym zrozumiałe wydaje się, że kapitał nie podejmuje prób ich rozłożenia, lecz przekształca istniejące sposoby artykulacji tej wspólnoty i wykorzystuje je do własnych celów.

Wraz z zaangażowaniem się kapitału w sektor szkolnictwa wyższego i przekształcenie go w jeden z wielu sektorów produkcji, forma, którą przyjmowała przez setki lat produkcja akademicka, z jej rywalizacją o prestiż w nauce, została w dużym

\footnotetext{
${ }^{3}$ Pisząc o elitach akademickich, nie mamy na myśli najbardziej płodnych i produktywnych naukowców, ale tych, którzy spajają ze sobą wypracowane na pewnym etapie osiągnięcia naukowe z pozycjami, które umożliwiają daleko idąca instytucjonalną władzę nad polem.
} 
stopniu zachowana. Co więcej, to ona, w swojej najogólniejszej postaci zapośredniczonej w globalnych rankingach uniwersytetów, stanowi dziś o głównym mechanizmie wytwarzania nierówności między uczonymi, instytucjami czy systemami krajowymi w skali globalnej. Jednak znów, opierając sie na hierarchii istniejącej we wspólnocie akademickiej, jej elity są w stanie uniknąć większości negatywnych konsekwencji dotykających pracowników naukowych w efekcie transformacji sektora. Podczas gdy elity akademickie w systemach znajdujących się na pozycjach centralnych globalnego podziału pracy są w stanie czerpać korzyści z opanowanych przez siebie „centrów konsekracji” (Münch 2014), to znaczy z kontroli nad wydawaniem czasopism czy serii wydawniczych decydujących o dystrybucji prestiżu w polu, w przypadku elit systemów peryferyjnych władza sprawowana przez oligarchię akademicką w polu naukowym umożliwia (oprócz szeregu innych korzyści) utrzymywanie się niejako poza stosunkami narzucanymi przez kapitał ${ }^{4}$.

\subsection{Sprzeczność realna (I): poddana rozkładowi forma tego, co wspólne i dobro wspólne}

Zanim przejdziemy do kolejnej sprzeczności, pierwszej spośród tych, które określamy mianem „realnych”, należy wyjaśnić pewne pojęcie. Wiele można napisać o dobru wspólnym. Poniżej odwołujemy się przede wszystkim do jego materialistycznego ujęcia. W tym miejscu chcielibyśmy zaś w kategoriach dobra wspólnego przeanalizować oligarchię akademicką. Jeśli przejście do uniwersytetu jako dobra wspólnego, czy też instytucji dobra wspólnego, ma być pomyślne, dobro wspólne w szkolnictwie wyższym musi się najpierw wyswobodzić z podwójnego uścisku kapitału oraz przedkapitalistycznych stosunków hierarchii właściwych oligarchicznej, quasi-feudalnej wspólnocie akademickiej, które określamy mianem poddanej rozkładowi formy dobra wspólnego.

W Rzeczy-pospolitej Michael Hardt i Antonio Negri piszą, że „każda instytucja społeczna istnieje dzięki dobru wspólnemu i w rzeczywistości jest przez nie definiowana. Potrzebuje go do swojego funkcjonowania, porządkuje je i tworzy"

${ }^{4}$ Pisze o tym w swojej najnowszej książce Marek Kwiek (2015), wskazując na uwarunkowania konfliktu pokoleniowego przenikającego polskie pole akademickie, w którym starsze i częstokroć znacznie mniej produktywne pokolenie akademików formułuje zasady oceny efektywności pracy akademickiej, zgodne z wymogami aktualnych trendów globalnych podporządkowujących pracę akademicką kapitałowi wydawniczemu, których na mocy sprawowanej przez siebie władzy nie musi stosować względem samego siebie. Oczywiście z naszej perspektywy tworzona w ten sposób opozycja między pokoleniami ma charakter pozorny. Właściwe pole antagonizmu leży tam, gdzie przecinają się interesy wytwórców badań i kapitału wydawniczego. Przywołany tu przykład służy wskazaniu funkcjonalności mechanizmów hierarchizacji wytwórców dla kapitału, jak również trwałej zdolności oligarchii akademickiej do koegzystencji z kapitałem, niezależnie od położenia danego systemu w globalnym podziale pracy akademickiej. 
(2012: 262-263). Nie inaczej jest z wielowiekową instytucją uniwersytetu. W jej istotę wpisane jest tworzenie, za pośrednictwem skupionej w nim wspólnoty akademickiej, dóbr wspólnych i dobra wspólnego. Jednak nie wszystkie postacie dobra wspólnego są równie korzystne. Hardt i Negri skupiają uwagę na trzech instytucjach społecznych występujących w kapitalizmie, w których dochodzi równolegle do produkcji dobra wspólnego i jego rozkładu. Instytucje te to: rodzina, korporacja i naród. Wszystkie one w określony sposób angażują i organizują dobro wspólne. Jednocześnie narzucają jego rozwojowi blokady, przecinając je licznymi hierarchiami, „redukując moce społecznej produkcji” (2012: 263), karząc za alternatywne względem wyznaczanych przez ustalony porządek praktyki (2012: 264) czy stosując wykluczenie i podział. Jak piszą w Rzeczy-pospolitej: „instytucje te występują jako sieci produktywnej kooperacji, w pełni dostępne zasoby bogactwa oraz obiegi komunikacji, które zaostrzają pragnienie dobra wspólnego i niweczą je zarazem" (2012: 268). W ten sposób, mimo istotnego pobudzania pragnienia dobra wspólnego, ostatecznie uniemożliwiają jego spełnienie, naznaczając wytwarzane w swoich ramach dobro wspólne cechami rozkładu. Stanowią więc względem kapitału towarzyszące formy ograniczania dobra wspólnego. Jak wyraźnie podkreślają Hardt i Negri, nie da się jednak przecenić ich znaczenia dla organizacji i reprodukcji dobra wspólnego, co czyni je istotnymi punktami wyjścia dla projektów emancypacji spod władzy kapitału.

Za tak rozumianą, skorumpowaną czy poddaną rozkładowi instytucję dobra wspólnego można również uznać hierarchiczny i przedkapitalistyczny uniwersytet, którego pozostałości wciąż można jeszcze odnaleźć w kolegialnych formach demokracji reprezentatywnej czy cechowych niemalże sposobach organizacji nauki w sieci towarzystw i podległych im czasopism naukowych, jak również w mechanizmach wewnętrznego regulowania życia wspólnoty. Nie jest to oczywiście jedyna instytucja społeczna tworząca ograniczające produktywność dobra wspólnego hierarchie w polu akademickim. Niezbędny dla wyznaczania hierarchii w polu akademickim prestiż i status, będące mechanizmami regulacji wspólnoty akademickiej, stały się dziś podstawą kapitalistycznej miary, wykorzystywanej nie tylko do dzielenia i hierarchizowania obszarów szkolnictwa wyższego na skalę globalną, ale również wzmożenia i przyspieszenia pracy akademickiej na całym świecie. Odbywający się poza kontrolą wspólnoty akademickiej wyścig o prestiż, którego punktem wyjścia było uruchomienie w $2003 \mathrm{r}$. pierwszego globalnego rankingu uniwersytetów (Liu i Cheng 2005; Hazelkorn 2011), jest obecnie jedną z głównych przeszkód w rozwoju nauki i edukacji wyższej. Przeinwestowane instytucjonalne giganty, odtwarzane z mniejszym czy większym powodzeniem w różnych regionach globu, akumulują zasoby na tak dużą skalę, że kolejny ich przyrost nie zwiększa już istotnie naukowej produktywności (Münch 2014). Walka o wyniki w nauce, które mogłyby odpowiadać na żywotne potrzeby społeczeństw (nie kapitału) na całym świecie, w coraz większym stopniu wypierana zostaje przez zmagania o ilościowo 
mierzalne osiągnięcia, które tylko częściowo pokrywają się ze społecznym zapotrzebowaniem. Niezależnie od tego cały ruch w nauce wpisany jest w procesy pomnażania wartości handlowej frakcji transnarodowego stowarzyszenia kapitału. Warto podkreślić, że istnienie antynomii między prestiżem a otwartą, opartą na dobru wspólnym nauką w produktywnym naprężeniu było jej motorem na etapie przedkapitalistycznym. Współczesne podporządkowanie mechanizmów regulujących status w polu akademickim kapitałowi usunęło z tej antynomii ostatnie znamiona produktywności, przekształcając ją w sprzeczność o niedialektycznym charakterze. Dziś jedyną drogą odzyskania tego, co wspólne, stanowiącego nieusuwalną podstawę wszelkiej pracy poznawczej, jest ostateczne pożegnanie się z indywidualizującą pozycyjną grą o status w nauce. Będzie to punkt wyjścia do wykroczenia poza relacje z kapitałem (Hardt i Negri 2012).

\subsection{Sprzeczność realna (II): dobro wspólne i kapitał}

Sprzecznością o najbardziej fundamentalnym charakterze jest ta zachodząca między dobrem wspólnym a kapitałem. Można powiedzieć, że jeden i drugi jej człon są ogólnymi postaciami stosunku społecznego, matrycą odwzorowania porządku tego, co społeczne. Dobro wspólne jest zarówno tym, co obecnie wyzyskuje i wywłaszcza kapitał, jak również podstawą autonomicznej i demokratycznej produkcji (Roggero 2010). Teoretycy różnej proweniencji, również zdeklarowani marksiści, poświęcili do tej pory wiele uwagi kapitałowi i jego potędze. Na podstawie ich rozważań można sądzić, że jest on zdolny nie tylko do nieskończonego rozwoju, ale również do rozwoju zupełnie samodzielnego, niesionego wpisanymi w niego sprzecznościami czy siłą konkurencji między tworzącymi go frakcjami. Jest to jednak błędne przekonanie. Stanowi ono bowiem rezultat przyjęcia za pewnik zafałszowania, którego dokonuje kapital, ogólnego fetyszyzmu, który stanowi podstawę jego stabilnego funkcjonowania. Relacje między kapitałem a dobrem wspólnym należy bowiem widzieć jako relację niedialektyczną. Nie stanowią one razem jakiegoś rodzaju ,jedności przeciwieństw", ale raczej dwa osobne byty, z których w dodatku jeden, mimo pasożytniczego charakteru drugiego, zdolny jest do samodzielnej egzystencji.

Mimo autonomicznego charakteru dobra wspólnego do jego wyswobodzenia nie wystarczy walka z formą własności prywatnej wiedzy. Kontrola, jaką sprawuje kapitał, rozciąga się dziś znacznie szerzej. Skupienie się wyłącznie na stosunkach własności wytworów wiedzy jest niewystarczające. Kapitał jest w stanie pójść na kompromis w tej dziedzinie, czego dowodzą choćby strategie dużych akademickich wydawców obliczone na przechodzenie w tryb świadczenia usług i pobierania APC (article processing charge) (Eve 2014). Jedyne, z czego kapitał dobrowolnie nie zrezygnuje, to ogólna dominacja nad polem, czyli władza (często realizowana po- 
przez działania państwa) do narzucania reguł społecznych (np. logiki stojącej za prawem wartości), według których całe życie społeczne jest następnie organizowane (Cleaver 1992). Taki efekt jest możliwy do osiągnięcia za pomocą politycznie ustanawianej miary. Nie oznacza to oczywiście, że walki toczone w obszarze własności wiedzy, otwieranie zasobów edukacyjnych czy zachowywanie otwartego dostępu do wytworów wiedzy, zarówno przeszłej, jak i obecnej, nie mają istotnego znaczenia. Walki o otwarty dostęp do wiedzy stanowią krok na drodze odzyskiwania warunków reprodukcji autonomicznie organizującej się wspólnoty wytwórców wiedzy. Jeśli jednak chcemy wyrwać się z uścisku kapitału, nie można na nich poprzestać.

Tak jak w przypadku poddanej rozkładowi formy dobra wspólnego hierarchiczne stosunki w szkolnictwie wyższym w dużej mierze opierają się na mechanizmach regulujących ekonomię statusu, tak w przypadku sprzeczności między dobrem wspólnym a kapitałem podstawową relacją dominacji jest nie stosunek własności, ale pomiar i miara. Rozszczepienie między kapitałem a dobrem wspólnym nie może jednak zakładać powrotu do przedkapitalistycznej rzeczywistości. Odrzucenie miary nie może pociągać za sobą ponownego oparcia regulacji na czystych i hierarchicznych stosunkach feudalnej akademii. Wykraczanie poza stosunki wyzysku i dominacji kapitału w szkolnictwie wyższym było i jest nadal dokonowane za pomocą wielu inicjatyw tworzących instytucje dobra wspólnego.

\section{Uniwersytet jako dobro wspólne}

Wszystkie strategie obliczone na odzyskiwanie instytucji uniwersytetu powinny kierować się radykalną zasadą aktywnej i realnej równości oraz w pełni demokratycznej kontroli. Walka o zniesienie sztucznych, feudalnych hierarchii na uniwersytetach powinna zatem zostać poprzedzona rozpoznaniem produktywnych funkcji, jakie pełnią wszyscy jego członkowie, przede wszystkim studenci i studentki, doktoranci i doktorantki, ale również pracownicy administracyjni i techniczni (Neary 2016).

Powinno to prowadzić do realizowania idei uniwersytetu jako kooperatywy wytwórców (Winn 2015), w której wszyscy będą posiadać głos i możliwość rozwijania i zaspokajania swoich potrzeb i pasji. W tym właśnie kontekście możemy odpowiedzieć na pytanie, jak powinno wyglądać postkapitalistyczne szkolnictwo wyższe. Powinno ono być doświadczeniem samodzielności niesprowadzającej się do indywidualizmu; przyjęciem etosu bazującego na zasadach współpracy ukierunkowanej na rozwój nauki, a nie autotelicznej konkurencji; wrogą wszelkim dogmatom, bezwzględną krytyką wszystkiego, co istnieje; ruchem, który znosi stan obecny. Formułując strategie demokratyzacji uniwersytetu, nie możemy jednak zapominać o jego uwikłaniu w interesy społeczeństwa i gospodarki. „Wolny uniwersytet w środku kapitalistycznego społeczeństwa jest jak czytelnia w więzieniu”, 
pisał w trakcie okupacji kampusów kalifornijskich uniwersytetów z 2009 r. kolektyw Research and Destroy (2011). Założenie o specyficzności uniwersytetu jest dziś niestety trudniejsze do utrzymania niż kiedykolwiek wcześniej. Chociaż cień „komunistycznego etosu nauki”, o którym pisał Robert Merton, kładący się wciąż na tej instytucji, podtrzymuje nadzieję na to, że uniwersytet pozostaje dziś dogodniejszą niż inne przestrzenią do rozwijania demokratycznych i równościowych projektów, to nie zmienimy go bez jednoczesnych starań o przekształcenie stosunków społecznych. Uniwersytet zaś stanowi dla nich wciąż bardzo dobry punkt wyjścia.

Mówiąc inaczej, uniwersytet dobra wspólnego nie będzie rezultatem działania automatycznego i dialektycznego ruchu koniecznych i bezwzględnych praw rozwoju historycznego. Nie powstanie na zgliszczach neoliberalnego uniwersytetu, spontanicznie rozsadzonego przez jego realne sprzeczności. Nie powinno to jednak być powodem do nadmiernego pesymizmu. Historycznie rzecz ujmując, rozwój uniwersytetu tworzy warunki sprzyjające wyzwoleniu. Jak twierdzi wielu krytycznych badaczy szkolnictwa wyższego, materialnym przejawem tego jest właśnie dobro wspólne, które stanowi rdzeń nie tylko przedsięwzięć akaemickich, ale i kapitalistycznej gospodarki opartej na wiedzy, której zasadom podporząadkowywany jest współczesny uniwersytet. Uniwersytet dobra wspólnego jest zatem czymś, o co musimy nieustannie walczyć.

\section{Literatura}

Angelis, M. de (2007). The Beginning of History. Value Struggles and Global Capital. London: Pluto Press.

Ball, S., Youdell, D. (2008). Hidden Privatisation in Public Education. Brussels: Education International.

Barnett, R. (2015). In Search of a Public: Higher Education in a Global Age. W: O. Filippakou, G. Williams (red.). Higher Education as a Public Good. Critical Perspectives on Theory, Policy and Practice (15-28). New York: Peter Lang.

Berman, E.P. (2012). Creating the Market University. How Academic Science Became an Economic Engine. Princeton: Princeton University Press.

Braudel, F. (1998). Kultura materialna, gospodarka i kapitalizm. XV-XVIII wiek, t. 2: Gry wymiany. Tłum. E.D. Żółkiewska. Warszawa: PIW.

Breneman, D.W. (2006). The University of Phoenix. Icon of For-Profit Higher Education. W: D.W. Breneman, B. Pusser, S.E. Turner (red.). Earnings From Learning. The Rise of For-Profit Universities (71-92). New York: SUNY Press.

Cantwell, B. (2016). The New Prudent Man: Financial-Academic Capitalism and Inequality in Higher Education. W: S. Slaughter, B.J. Taylor (red.). Higher Education, Stratification, and Workforce Development. Competitive Advantage in Europe, the US, and Canada (173-192). Dordrecht: Springer.

Cantwell, B., Kauppinen, I. (red.) (2014). Academic Capitalism in the Age of Globalization. Baltimore: The Johns Hopkins University Press. 
Clark, B.R. (1983). The Higher Education System. Academic Organization in Cross-National Perspective. Berkeley - Los Angeles: University of California Press.

Clark, B.R. (1998). Creating Entrepreneurial Universities. Organizational Pathways of Transformation. Bingley: Emerald Group Publishing Limited.

Cleaver, H. (1992). Theses on the Secular Crisis; https://la.utexas.edu/users/hcleaver/secularcrisis.html [31.12.2015].

Edu-factory Collective (2009). Towards a Global Autonomous University. New York: Autonomedia.

Edu-factory Collective (2010). Double crisis. Edu-factory. 0: 4-9.

Eve, M.P. (2014). Open Access and the Humanities. Contexts, Controversies and the Future. New York: Cambridge University Press.

Ferlie, E., Musselin, Ch., Andresani, G. (2008). The Steering of Higher Education Systems. A Public Management Perspective. Higher Education. 56(3): 325-348.

Haiven, M. (2014). Crisis of Imagination, Crisis of Power. Capitalism, creativity and the commons. London: Zed Books.

Hall, R. (2014). On the Abolition of Academic Labour: The Relationship Between Intellectual Workers and Mass Intellectuality. tripleC: Communication, Capitalism \& Critique. 12(2): 822-837.

Hall, R. (2015). The implications of Autonomist Marxism for research and practice in education and technology. Learning, Media and Technology. 40(1): 106-122.

Hardt, M., Negri, A. (2012). Rzecz-pospolita. Poza własność prywatna i dobro publiczne. Tłum. Praktyka Teoretyczna. Kraków: Wyd. ha!art.

Harvey, D. (2014). Seventeen Contradictions and the End of Capitalism. London: Oxford University Press.

Hazelkorn, E. (2011). Rankings and the Reshaping of Higher Education. The Battle for World-Class Excellence. Basingstoke: Palgrave Macmillan.

Hazelkorn, E. (2013). World-class universities or world-class systems? Rankings and higher education policy choices. W: P.T.M. Marope, P.J. Wells, E. Hazelkorn (red.). Rankings and Accountability in Higher Education. Uses and Misuses (72-94). Paris: UNESCO Publishing.

Hess, Ch., Ostrom, E. (red.). (2007). Understanding Knowledge as Commons: From Theory to Practice. Cambridge: The MIT Press.

Horkheimer, M. (1987). Teoria tradycyjna a teoria krytyczna. Tłum. J. Łoziński. W: J. Łoziński (red.), Szkoła frankfurcka (t. 2, 138-172). Warszawa: Wyd. IFiS PAN.

Iljenkow, E. (1978). Logika dialektyczna. Tłum. W. Krzemień. Warszawa: PIW.

Jongbloed, B. (2003). Marketisation in Higher Education: Clark's Triangle and the Essential Ingredients of Markets. Higher Education Quarterly. 57(2): 110-135.

Kwiek, M. (2010). Transformacje uniwersytetu. Zmiany instytucjonalne i ewolucje polityki edukacyjnej w Europie. Poznań: Wyd. Naukowe UAM.

Kwiek, M. (2015). Uniwersytet $w$ dobie przemian. Instytucje i kadra akademicka $w$ warunkach rosnacej konkurencji. Warszawa: Wyd. Naukowe PWN.

Latour, B. (2011). Nigdy nie byliśmy nowocześni. Studium z antropologii symetrycznej. Tłum. M. Gdula. Warszawa: Oficyna Naukowa. 
Leslie, L., Slaughter, S. (1998). Academic Capitalism. Politics, Policies and Entrepreneurial University. Baltimore: The Johns Hopkins University Press.

Liu, N.C., Cheng, Y. (2005). The Academic Ranking of World Universities. Higher Education in Europe. 30(2): 127-136.

Łukasiewicz, J. (1987). O zasadzie sprzeczności u Arystotelesa. Warszawa: Wyd. Naukowe PWN.

Marginson, S. (2004). Competition and Markets in Higher Education: A „glonacal” analysis. Policy Futures in Education. 2(2): 175-244.

Marginson, S. (2006). Putting „Public” Back into the Public University. Thesis Eleven. 84: 44-59.

Marginson, S. (2007). Five Somersaults in Enschade: Rethinking Public/Private in Higher Education for the Global Era. W: J. Enders, B. Jongbloed (red.), Public-Private Dynamics in Higher Education. Expectations, Development and Outcomes (187-219). Bielefeld: Transcript Verlag.

Marginson, S., Ordorika, I. (2011). „El central volume de la fuerza”. Global Hegemony in Higher Education and Resaerch. W: D. Rhoten, C. Calhoun (red.), Knowledge Matters. The Public Mission of the Research University (67-129). New York: Columbia University Press.

Marks K. (1984). Kapitat: Krytyka ekonomii politycznej. Księga III: Proces produkcji kapitalistycznej jako całość. Tłum. E. Lipiński, J. Maliniak. W: MED, t. 25, cz. 1, Warszawa: Książka i Wiedza.

McGettigan, A. (2013). The Great University Gamble. Money, Markets and the Future of Higher Education. London: Pluto Press.

Moulier Boutang, Y. (2011). Cognitive capitalism. Tłum. E. Emery. Cambridge: Polity Press.

Münch, R. (2014). Academic Capitalism. Universities in the Global Struggle for Excellence. Cambridge: Polity Press.

Neary, M. (2016). Student as Producer: The Struggle for the Idea of the University. Other Education: The Journal of Educational Alternatives. 5(1): 89-94.

Neave, G. (2012). The Evaluative State, Institutional Autonomy and Re-engineering Higher Education in Western Europe. The Prince and His Pleasure. Palgrave Macmillan: Basingstoke.

Negri, A. (2003). Time for Revolution. Tłum. M. Mandarini. London: Bloomsbury Academic.

Oliveira, M.B. (2013). On the Commodification of Science: The Programmatic Dimension. Science \& Education. 22(10): 2463-2483.

Ostrom, E. (1990). Governing the Commons: The Evolution of Institutions for Collective Action. Cambridge: Cambridge University Press.

Peekhaus, W. (2012). The Enclosure and Alienation of Academic Publishing: Lessons for the Professoriate. tripleC. 10(2): 577-599.

Ratajczak, M. (2015). Wprowadzenie do teorii kapitalizmu kognitywnego: kapitalizm kognitywny jako rezim akumulacji. Praktyka Teoretyczna. 1(15): 57-94.

Research and Destroy (2011). Communiqué from an Absent Future: On the Terminus of Student Life. W: C. Solomon, T. Palmieri (red.), Springtime. The New Student Rebellions (151-160). London: Verso. 
Roggero G. (2011a). The Production of Living Knowledge: the Crisis of the University and the Transformation of Labor in Europe and North America. Tłum. E. Brophy. Philadelphia: Temple University Press.

Roggero, G. (2011b). Pięć tez o dobru wspólnym. Tłum. P. Juskowiak, K. Szadkowski. Praktyka Teoretyczna. 4: 69-84.

Schrecker, E. (2010). The Lost Soul of Higher Education. Corporatization, the Assault on Academic Freedom, and the End of the American University. New York: The New Press.

Slaughter, S., Rhoades, G. (2004). Academic Capitalism in the New Economy. Challenges and Choices. American Academic. 1(1): 37-59.

Śpiewak, P. (1998). W stronę dobra wspólnego. Warszawa: Aletheia.

Stiglitz, J. (1999). Knowledge as a Global Public Good. W: I. Kaul, I. Grunberg, M. Stern (red.). Global Public Goods: International Cooperation in the $21^{\text {st }}$ Century (308-325). New York - Oxford: Oxford University Press.

Szadkowski, K. (2015a). Uniwersytet jako dobro wspólne. Podstawy krytycznych badań nad szkolnictwem wyższym. Warszawa: Wyd. Naukowe PWN.

Szadkowski, K. (2015b). Poza uniwersytet-fabrykę. Warunki funkcjonowania „transnarodowego stowarzyszenia kapitałów” w szkolnictwie wyższym. Nauka i Szkolnictwo Wyższe. 1(45): $235-267$.

Szadkowski, K. (2015c). Teza o hybrydyzacji tego, co publiczne i tego, co prywatne w szkolnictwie wyższym oraz jej konsekwencje. Próba krytyki. Nauka i Szkolnictwo Wyższe 2(46): 65-110. DOI: 10.14746/nsw.2015.2.3

Vercellone, C. (2010). The Crisis of the Law of Value and the Becoming-Rent of Profit. Tłum. J. F. McGimsey. W: A. Fumagalli, S. Mezzadra (red.), Crisis in the Global Economy: Financial Markets, Social Struggles and the New Political Scenarios (85-118). Los Angeles: The MIT Press.

Winn, J. (2015). The co-operative university: Labour, property and pedagogy. Power \& Education. 7(1): 39-55.

\title{
Basic contradictions of the higher education subsumed under capital. Towards systematic approach
}

\begin{abstract}
This theoretical article explores four main contradictions of the contemporary higher education subsumed under capital. It does so basing on author's previous research results and with the use of general Marxian and Autonomist Marxist theoretical frameworks developed by authors like Michael Hardt, Antonio Negri and Gigi Roggero, and applied recently to critical higher education research. The contradictions are divided into two main categories: the apparent contradictions (the public vs. the private; academic oligarchy vs. capital) and the real contradictions (corrupted form of the common vs. the common; the common vs. capital). They are discussed respectively with reference to contemporary higher education reality. The final part of the article shortly discusses the already existing preconditions for establishing of a post-capitalist university regulated according to the logic of the common.
\end{abstract}

KEYWORDS: the common, higher education, university, subsumption, capital, the public, the private 
CYTOWANIE: Szadkowski, K. (2015). Podstawowe sprzeczności podporządkowanego kapitałowi szkolnictwa wyższego. W stronę systematyzacji. Nauka i Szkolnictwo Wyższe. 2(46): 161-181. DOI: 10.14746/nsw.2015.2.6. 